\title{
Advanced Lung Small Cell Carcinoma
}

National Cancer Institute

\section{Source}

National Cancer Institute. Advanced Lung Small Cell Carcinoma. NCI Thesaurus. Code C160296.

Small cell lung carcinoma that has spread extensively to other anatomical sites or is no longer responding to treatment. 